\title{
SIMULATIONS OF SEISMIC ACTIVITY IN THE CORINTH GULF, GREECE, FAULT SYSTEM
}

\author{
Console R. ${ }^{1,2}$, Carluccio R. ${ }^{2}$, Papadimitriou E. ${ }^{3}$ and Karakostas V. ${ }^{3}$ \\ ${ }^{1}$ Center of Integrated Geomorphology for the Mediterranean Area, 85100, Potenza, Italy, \\ r.console@cgiam.org,rodolfo.console@ingv.it \\ ${ }^{1}$ Istituto Nazionale di Geofisica e Vulcanologia, 00143, Roma, Italy, roberto.carluccio@ingv.it \\ ${ }^{1}$ Aristotle University of Thessaloniki, Geophysics Department, 54124, Thessaloniki, Greece, \\ ritsa@geo.auth.gr,vkarak@geo.auth.gr
}

\begin{abstract}
The characteristic earthquake hypothesis is not strongly supported by observational data because of the relatively short duration of historical and even paleoseismological records. For instance, for the Corinth Gulf Fault System (CGFS), historical information on strong earthquakes exist for at least two thousand years, but they can be considered complete for $M>6.0$ only for the latest 300 years, and therefore only few characteristic earthquakes are reported for individual fault segments.

The use of a physics-based earthquake simulator has allowed the production of catalogues lasting 100,000 years and containing more than 500,000 events of magnitudes $>4.0$. Our simulation algorithm is based on several physical elements, such as an average slip rate due to tectonic loading for every single segment in the investigated fault system, the process of rupture growth and termination, and interaction between earthquake sources, including small magnitude events.

The application of our simulation algorithm to the CGFS provided realistic features in time, space and magnitude behaviour of the seismicity. These features include longterm periodicity of strong earthquakes, short-term clustering of both strong and smaller events, and a realistic earthquake magnitude distribution departing from the Gutenberg-Richter distribution in the moderate and higher magnitude range.

Keywords: Corinth Gulf seismicity, characteristic earthquake, earthquake simulator, magnitude distribution.
\end{abstract}

\section{Introduction}

The characteristic earthquake hypothesis was introduced more than thirty years ago (Shimazaki and Nakata, 1980; Schwartz and Coppersmith, 1984) and although debated, has been widely applied since then. The basic idea of this hypothesis, following the elastic rebound theory of Reid (1910), is that earthquakes exhibit a general trend to repeat themselves along the same fault segment. A characteristic earthquake ruptures the entire segment and relieves tectonic stress across the segment. Assuming a constant stressing rate and a constant strength on the fault, a consequence of this model is that the time interval between consecutive characteristic earthquakes is described by a renewal model with a relatively small coefficient of variation. Typically a renewal model predicts that hazard is small immediately following the previous large earthquake and increases with time since the latest event on a certain fault segment. 
In spite of its popularity, the characteristic earthquake hypothesis in connection with fault segmentation is not fully supported by observational evidence. For instance, focusing on eight fault segments consisting an almost continuous fault zone bounding the southern coastline of the Corinth Gulf (Greece), Console et al. (2013) found poor evidence for a better performance of the renewal model based on the characteristic earthquake hypothesis than the time-independent Poisson model.

A variant of the plain characteristic earthquake hypothesis includes the possibility that two or more segments rupture simultaneously, giving rise to larger magnitude events (called cascade-events in the reports of the WGCEP published in 1995 and 2002 (Field, 2007)). Recently, the concept of unsegmented faults, comprising more than one known fault segment where earthquakes of any magnitude may occur regardless of an a-priori segmentation scheme, was considered by several authors (Weldon et al., 2005; Field and Page, 2011; Parsons, 2012 among others). Recognizing the possibility that earthquakes may occur across segment boundaries, a more recent report of the WGCEP (2008) followed also the option of considering unsegmented faults, as an alternative to the afore-mentioned models considering segmentation.

Testing and validating different hypotheses of long-term earthquake occurrence remains a challenging problem. In fact, in the study of the largest earthquakes, our observation record is too short and incomplete for statistical assessment of such models. To overcome these difficulties, the application of earthquake simulators, which can span periods of time much longer than our temporally-constrained observations, has been proved effective in several investigations.

Rather powerful algorithms were recently developed to model long histories of earthquake occurrence and associated coseismic slip using various approximations of what is known about the physics of stress transfer due to the fault slip and the rheological properties of faults. In particular, these algorithms were successfully applied to a model encompassing a comprehensive set of faults in California (Tullis, 2012). These physics-based earthquake simulators can reproduce dynamic rupture on geographically correct and complex systems of interacting faults (e.g. Ward, 2012; Richards-Dinger and Dieterich, 2012).

In the present study we aim to follow the work done by the above mentioned authors for simulating the seismic activity in the Corinth Gulf (Greece) Fault System (CGFS). Although based on some of the principles adopted in those papers, our simulation algorithm has been independently developed, aiming at demonstrating that a model characterized by a few, simple and reasonable assumptions allows the replication not only of the spatial features, but also of the temporal behaviour and the scaling laws of the observed seismicity.

\section{The seismicity of the Corinth Gulf Fault System}

The Gulf of Corinth is one of the sites of the back arc Aegean region where active extension is localized. It forms in general an asymmetric half graben in an almost east-west direction, with an uplifted southern footwall and downward flexed hanging wall with minor antithetic faulting. In the last decades there have been intensive investigations of the active deformation through geodetic measurements, in particular GPS measurements. They give an N-S extension of about $15 \mathrm{~mm} \cdot \mathrm{yr}^{-1}$ in the western part of the Gulf, and about $10 \mathrm{~mm} \cdot \mathrm{yr}^{-1}$ in the eastern part (Billiris et al., 1991; Clarke et al., 1997; Davies et al., 1997; Briole et al., 2000). A larger extension in the western part that decreases to the east has repeatedly been confirmed (e.g. Choussianitis et al., 2013).

The fault segments that are mainly associated with seismicity are the north-dipping ones that bound the Gulf to the south, namely the Psathopyrgos, Aigion, Eliki, Offshore Akrata and Xylokastro fault segments in the western and central parts of the Gulf, and the Offshore Perachora, Skinos and Alepohori fault segments in its eastern part (Fig. 1). Most of the well-determined mechanisms indicate that the western fault segments have an average strike of $\mathrm{N} 90-105^{\circ} \mathrm{E}$ under a N-S extension, a nodal plane with a northward dip of about $50^{\circ}$ near the surface and $10-25^{\circ}$ at the bottom of the seismogenic layer and a steep south-dipping plane (Jackson, 1987; Taymaz et al., 1991; Hatzfeld et 
al., 1996; Bernard et al., 1997; Baker et al., 1997). This is also the case for microearthquake mechanisms (Hatzfeld et al., 1990, 2000; Rigo et al., 1996). At the eastern extremity of the Gulf, the main active normal fault segments strike more north-eastwards (N70-90 $\left.{ }^{\circ} \mathrm{E}\right)$ and cut obliquely across both structures and the relief. Geological and morphological observations were modelled and gave an opening rate of $11 \pm 3 \mathrm{~mm} \mathrm{yr}^{-1}$ on the main rift-bounding fault over the last $350 \mathrm{kyr}$, which is more than 10 times higher than in the rest of the Aegean and elsewhere in the world (Armijo $e t$ al., 1996).

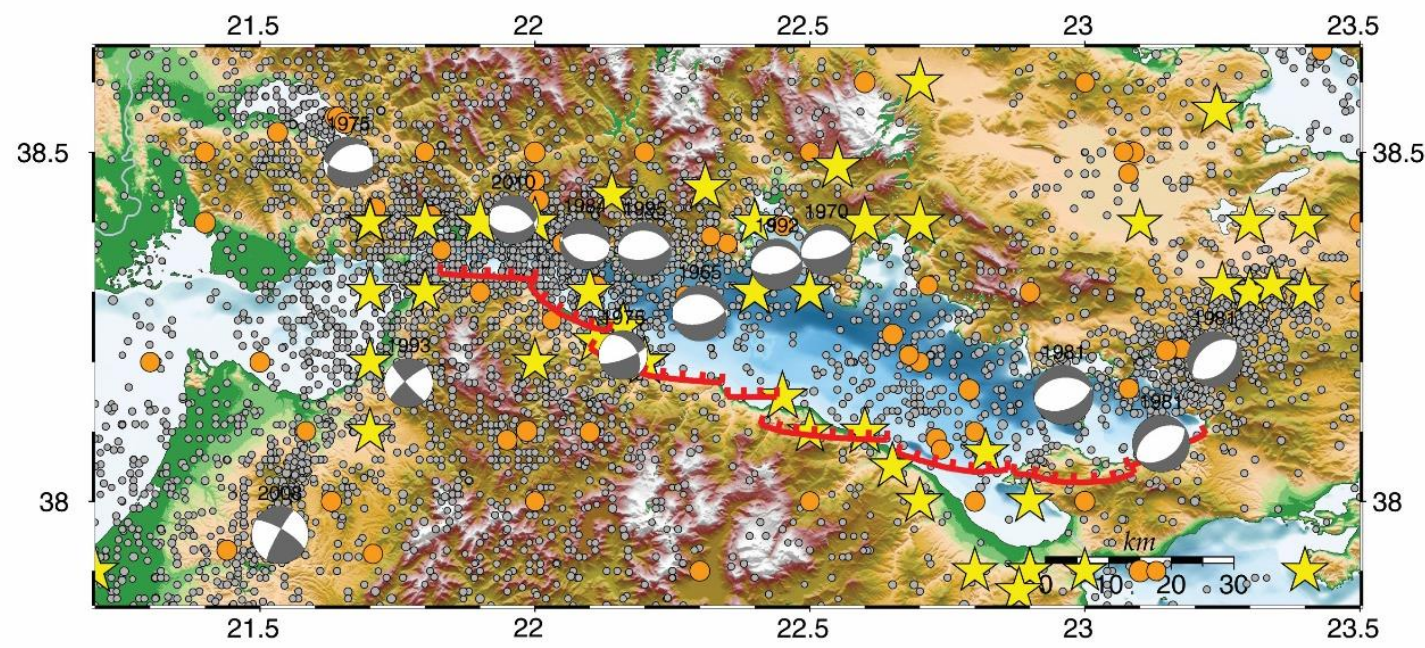

Figure 1 - Seismotectonic setting of the Corinth Gulf area with instrumental and historical seismicity along with the eight fault segments bounding the southern coastline that are included in our model. Small circles depict earthquakes of $M \geq 3.5$ since 1971, moderate circles the ones with $M \geq 5.0$ since 1911 and asterisks all known $M \geq 6.0$ earthquakes fault plane solutions of $M>5.5$ crustal earthquakes available from gcmt solutions (http://www.globalcmt.org/CMTsearch.html) are plotted as equal area lower hemisphere projections.

Table 1 - Parameters of the Corinth Gulf Fault Systems.

\begin{tabular}{|c|c|c|c|c|}
\hline Segment number & Segment name & $\begin{array}{c}\text { Length } \\
(\mathbf{k m})\end{array}$ & $\begin{array}{c}\text { Width } \\
(\mathbf{k m})\end{array}$ & $\begin{array}{c}\text { Slip rate } \\
(\mathbf{m m} / \mathbf{y r})\end{array}$ \\
\hline 1 & Psathopyrgos & 15 & 12 & 6 \\
\hline 2 & Aigion & 16 & 12 & 6 \\
\hline 3 & Eliki & 22 & 12 & 6 \\
\hline 4 & Offshore Akrata & 8 & 8 & 5 \\
\hline 5 & Xylokastro & 20 & 12 & 5 \\
\hline 6 & Offshore Perachora & 18 & 12 & 4 \\
\hline 7 & Skinos & 19 & 12 & 3 \\
\hline 8 & Alepochori & 13 & 12 & 3 \\
\hline
\end{tabular}

The eight fault segments are considered as a continuous fault zone in our model, information on which is given in Table 1. This consideration is supported by Jackson and McKenzie (1988) stating that the deformation of a zone at length-scales much larger than a single fault is best described as a continuum. Fault lengths do not exceed 20-25 km (Jackson and White, 1989), in accordance with the maximum magnitude of historical and instrumental earthquakes. However, it is not clear whether 
the discontinuities separating the different segments are stable and will never break, or whether occasionally the rupture can jump from one segment to another, thereby leading to an earthquake of greater magnitude (Jackson and White, 1989; Hatzfeld et al., 2000).

The strong $(M>6.0)$ earthquakes are quite frequent and the associated casualties are known from historical record going back for more than 25 centuries before our era (Papazachos and Papazachou, 2003; Ambraseys, 2009). The most notable is the 373 BC Eliki earthquake, which caused the sinking of this important city. Testimonies also exist about catastrophic earthquakes in Delphi Oracle and ancient Corinth. Recurrence intervals range from one to three centuries (Console et al., 2013 and references therein). The maximum known earthquake magnitude in the area is almost 7.0, which probably reflects the lack of fault continuity along the entire fault zone. The historical record of the last three centuries, which is considered complete for $\mathrm{M}>6.0$, is reported in Table 2.

Table 2 - Characteristic earthquakes of the southern CGFS since 1714 A.D.

\begin{tabular}{|c|c|c|c|c|c|c|}
\hline $\begin{array}{c}\text { Event } \\
\text { number }\end{array}$ & Year & Month & Day & M & Segment name & $\begin{array}{c}\text { Segment } \\
\text { number }\end{array}$ \\
\hline 1 & 1714 & 7 & 29 & 6.2 & Psathopyrgos & 1 \\
\hline 2 & 1742 & 2 & 21 & 6.7 & Xylokastro & 5 \\
\hline 3 & 1748 & 5 & 15 & 6.6 & Aigion & 2 \\
\hline 4 & 1753 & 3 & 6 & 6.1 & Xylokastro & 5 \\
\hline 5 & 1775 & 4 & 16 & 6.0 & Offshore Perachora & 6 \\
\hline 6 & 1806 & 1 & 24 & 6.2 & Psathopyrgos & 1 \\
\hline 7 & 1817 & 8 & 23 & 6.6 & Aigion & 2 \\
\hline 8 & 1861 & 12 & 26 & 6.7 & Eliki & 3 \\
\hline 9 & 1887 & 10 & 3 & 6.3 & Offshore Perachora & 6 \\
\hline 10 & 1888 & 9 & 9 & 6.3 & Aigion & 2 \\
\hline 11 & 1928 & 4 & 22 & 6.3 & Offshore Perachora & 6 \\
\hline 12 & 1965 & 7 & 6 & 6.3 & East part of Eliki & 3 \\
\hline 13 & 1970 & 4 & 8 & 6.2 & East part of Xylokastro & 5 \\
\hline 14 & 1981 & 2 & 24 & 6.7 & Skinos & 7 \\
\hline 15 & 1981 & 2 & 25 & 6.4 & Alepochori & 8 \\
\hline 16 & 1992 & 11 & 18 & 5.7 & Offshore Akrata & 4 \\
\hline 17 & 1995 & 6 & 15 & 6.5 & Aigion & 2 \\
\hline
\end{tabular}

\section{Algorithm of the simulator code}

The algorithm applied in this study was based on the concepts introduced for earthquakes simulators in California (Tullis, 2012) such as the constraint for the long term slip rate on fault segments, and the adherence to a physically based model of rupture growth, without making use of time-dependent rheological parameters on the fault. Because of its limited sophistication, our algorithm is suitable for the production of synthetic catalogues resembling the long-term seismic activity of relatively simple fault systems, including hundreds of thousands earthquakes of moderate magnitude, even using quite limited computing resources.

A detailed outline of the computer code is provided by Console et al. (2015). Here we recall only the main features of this algorithm. In the present version of the code, the seismogenic source is approximated as a rectangle, composed of a number of cells with assigned dimensions in alongstrike and down-dip directions. The rectangular fault is then divided into an arbitrary number of 
segments, without constituting any barrier to rupture growth. They have the only role of making it possible to assign different slip rates associated with tectonic loading onto each of them. Each cell is randomly assigned an initial stress budget within a given interval around an arbitrary average value. This is to accommodate our lack of knowledge about the initial status of stress and strength on each point of the fault.

The events are initiated one by one on the cell with the largest stress budget, but only if it exceeds a given stress threshold. The second ruptured cell of the specific event is chosen as that with the largest stress budget among the eight cells surrounding the nucleation cell, and so on for the next ruptured cells, until the stopping condition is met, when none of the cells, including and surrounding the ones previously ruptured in the same event, has a stress budget exceeding the threshold.

The simulation algorithm, in its simplicity, provides preference for new ruptures to nucleate at the points of the fault where the stress budget is higher, i.e. where the time elapsed since the latest event is longer. Once it is nucleated, the rupture expands in the directions where the stress budget is still higher, thus simulating a preference for filling pre-existing gaps and epicentre migration. Moreover, because of the stress transfer included in the model, earthquakes are more likely to occur close to the borders of the rupture of a preceding large earthquake, simulating a feature similar to aftershock production.

\section{Results}

\subsection{Application of the simulator}

In the application of the simulator, the rectangular source area representing the CGFS was discretized in cells of $0.5 \mathrm{~km} \times 0.5 \mathrm{~km}$. We chose for the synthetic catalogues a minimum magnitude of 4.0, which is produced approximately by the rupture of 6 cells. The duration of all the synthetic catalogues was 100,000 years. In order to explore the effect of the arbitrary choice of the free parameters used in the algorithm we carried out a series of simulations, each time using different combinations of these parameters (Console et al., 2015). In the following we shall consider only the results of a simulation obtained by the selection of free parameters that exhibits the best match between the magnitude distribution of the real and simulated catalogue (Fig. 2), taking into account the large difference in the scale of the total number of events, due to the different period spanned by the two catalogues.

Figure 2 shows a clear deviation of the magnitude distribution obtained by the simulation algorithm from a plain linear Gutenberg-Richter distribution, a feature that is consistent with the cumulative distributions obtained from real observations after 1911, also shown in Figure 2. The magnitude distribution exhibits a sharp "bump" around a value of magnitude that could be defined as "characteristic". It can be noted that the magnitude distribution of both the synthetic and the real catalogues is nearly flat (i.e. a b-value equal to 0 ) in the magnitude range $5.5<\mathrm{M}<6.5$. 


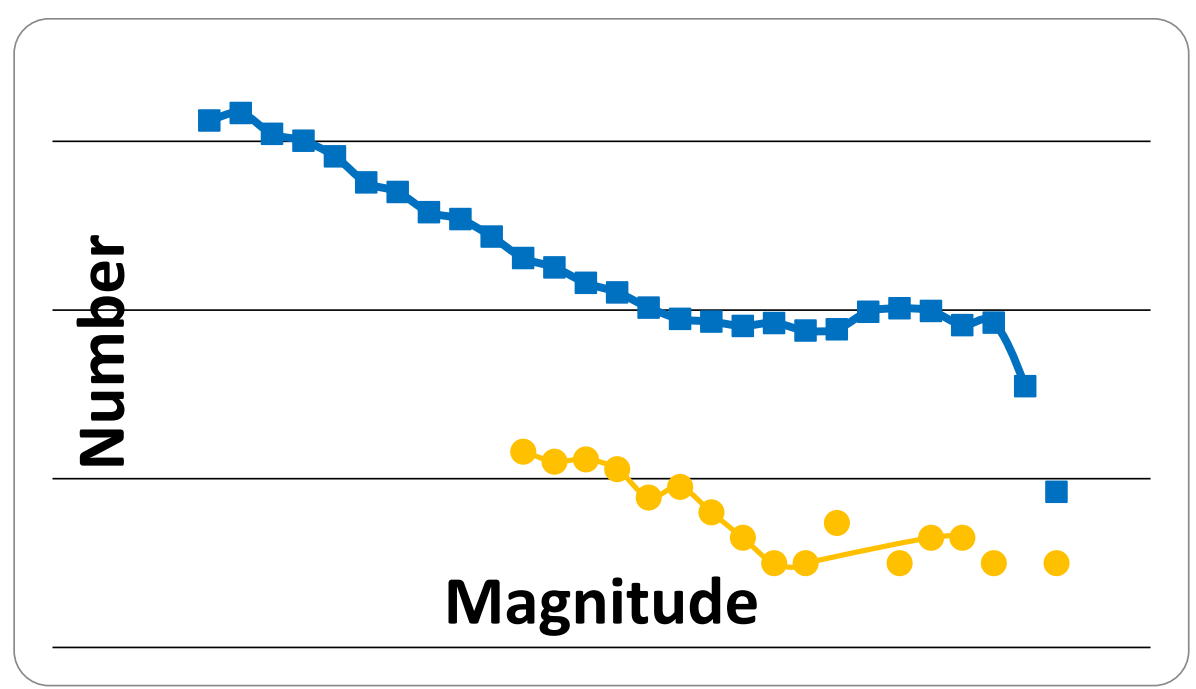

Figure 2 - Frequency-magnitude distribution of the earthquakes in the synthetic catalogue obtained from the simulation algorithm described in the text (squares). The bottom data (dots) concern earthquakes occurred in the study area starting in 1911.

\subsection{Temporal features of the synthetic catalogues}

In order to test the potential use of the simulation algorithm for drawing conclusions about the predictability of strong earthquakes, it is worth making a comparison between the synthetic and the real catalogue. However, this is not a trivial task, because the two kinds of catalogues are conceptually different. The list of 17 earthquakes of $M \geq 6.0$ (except that for event 16, having magnitude 5.7) reported in Table 1 for the latest 3 centuries, assumes that each event occurred on a single segment. Nevertheless, the magnitudes of earthquakes on the same segment are not the same. This implies that a single earthquake could have ruptured a single segment just partly for the smaller magnitudes, or have propagated to more than one segment for the larger magnitudes, in agreement with the assumption made in our simulation algorithm.

Aiming at reproducing an earthquake catalog resembling the features of the real one, the analysis was based upon some arbitrary criteria to attribute a specific earthquake to one or more segments. The rules adopted for this purpose are:

1) The earthquake must have a minimum magnitude of 6.0 ;

2) The earthquake is firstly assigned to the segment which contains the largest number of fractured cells;

3) The same earthquake can be also assigned to other segments if the number of cells ruptured by the event exceeds the number of 600 or at least $80 \%$ of the total number of cells for the specific segment.

It should be noted that the number of cells of the smallest segment in the fault system (number 4, offshore Akrata) is 384 (equivalent to a magnitude 5.9 earthquake), and that of the largest one (number 3, Eliki) is 1056 (equivalent to a magnitude 6.4 earthquake). An example of time-space plot of the synthetic catalogue obtained after applying the above mentioned criteria to the first 2500 years is shown by grey bars in Figure 3. For sake of comparison, this figure shows also the 17 earthquakes that occurred since $1700 \mathrm{AD}$ and are reported in Table 2 (black squares). 


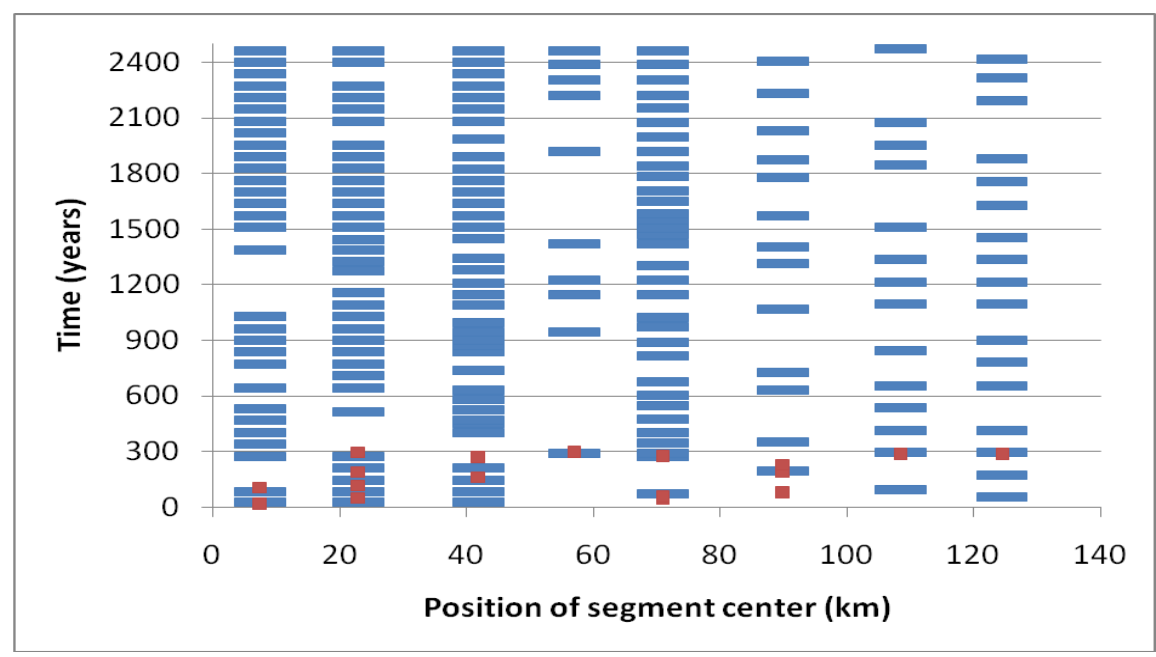

Figure 3 - Space-time features of the synthetic catalogue concerning earthquakes with $M>6.0$ for the first 2500 years (grey bars). Black squares show the occurrence time and location of the observed earthquakes reported in Table 2 (after Console et al., 2015).

A visual inspection of Figure 3 does not reveal any systematic behaviour that can be recognized as substantial discrepancy between the synthetic and the real catalogues. Note that Figure 3 displays all the ruptures that constitute a single earthquake as individual events. This justifies the apparent larger number of synthetic events with respect to those reported in the real catalog (which assigns each earthquake to a single segment, independently of its size). We observe a non-periodical time distribution, with inter-event times ranging from few years to hundreds of years on the same segment. We can also see earthquakes that rupture different segments as a unique event or more events that occur with very short time separation. This feature is not inconsistent with the historical observations. In fact, Table 2 reports doublets of events as numbers 9-10 (1887-1888) and numbers 14-15 (1981). Moreover, the two \#2 and \#4 (1742 and 1753) Xylokastro earthquakes are separated by only 11 years.

In order to assess whether the earthquake occurrence time on single segments in the synthetic catalogue behaves as a Poisson process or not, we carried out a statistical analysis of the inter-event times for the entire 100,000 years simulation. In this respect, Figure 4 shows the inter-event time distribution of the simulation. Table 3 displays the mean inter-event time $T_{r}$, the standard deviation $\sigma$ and the coefficient of variation $C_{v}$ for each segment. The relatively short average inter-event times of the simulations can be justified by the circumstance that often two or more segments rupture simultaneously in a single earthquake. Along with the above mentioned temporal parameters, Table 3 also reports the results of the difference between the log-likelihood computed by the Brownian Passage Time (BPT) renewal model and the Poisson time-independent model (dlogL). For the likelihood estimation we have adopted the values obtained for $T_{r}$ and $C_{v}$ reported in Table 3 for each fault segment.

Both Figure 4 and Table 3 show, as expected, that the most active segments are those characterized by larger size and higher slip rate (such as Psathopyrgos, Aigion, Eliki and Xylokastro). The simulation also shows that, especially for the less active segments (offshore Perachora, Skinos and Alepochori), inter-event times of several hundreds of years are possible. The coefficient of variation $C_{v}$ is typically close to 0.6 , which would be associated to a moderately time-predictable behaviour of the seismicity. The average $\log$-likelihood difference $(\operatorname{d} \log L / N)$ denotes a better performance of the renewal model against the time-independent hypothesis. The exception to this pseudo-periodical behaviour is presented by segment \#4 (Offshore Akrata), which exhibits a coefficient of variation slightly larger than 1 and a modest log-likelihood difference. 


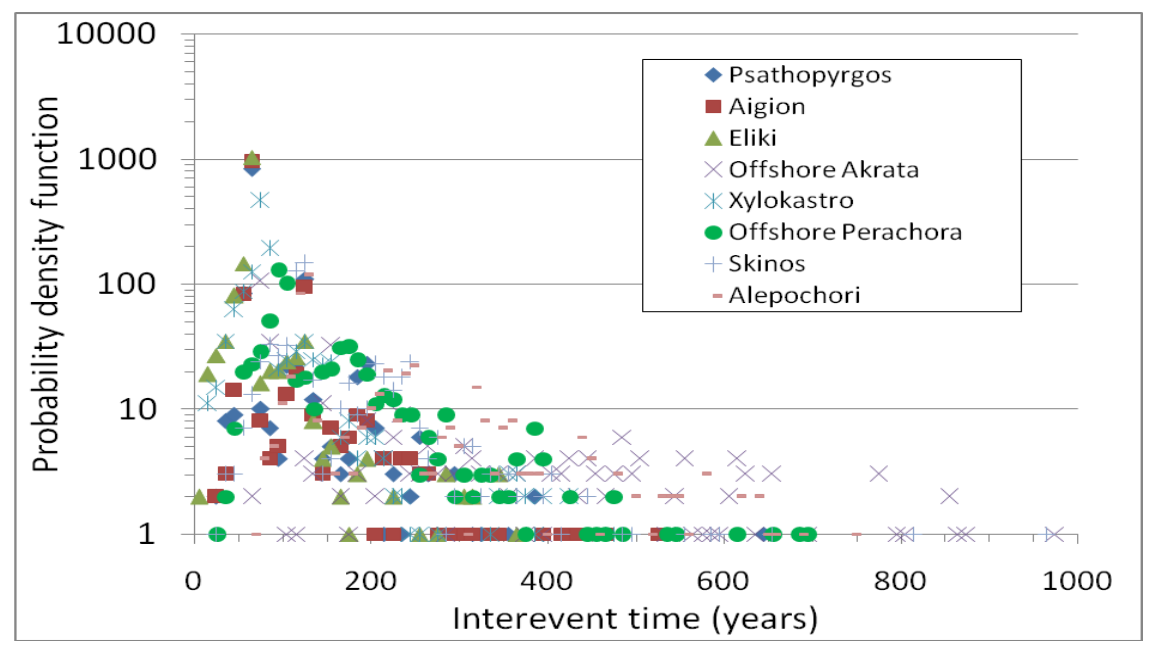

Figure 4 - Inter-event time distribution from a simulation of 100,000 years of seismic activity across the CGFS (after Console et al., 2015).

Table 3 - Statistical parameters of the synthetic catalogue.

\begin{tabular}{|l|c|c|c|c|}
\hline Segment number/name & $\boldsymbol{T}_{\boldsymbol{r}}(\mathbf{y r})$ & $\boldsymbol{\sigma}(\mathbf{y r})$ & $\boldsymbol{C}_{\boldsymbol{v}}$ & dlog$L / N$ \\
\hline 1. Psathopyrgos & 82.7 & 47.1 & 0.57 & 0.494 \\
\hline 2. Aigion & 78.7 & 45.2 & 0.57 & 0.505 \\
\hline 3. Eliki & 66.1 & 23.1 & 0.35 & 0.674 \\
\hline 4. Offshore Akrata & 276.4 & 298.0 & 1.08 & 0.165 \\
\hline 5. Xylokastro & 82.3 & 34.0 & 0.41 & 0.536 \\
\hline 6. Offshore Perachora & 146.9 & 89.2 & 0.61 & 0.380 \\
\hline 7. Skinos & 155.4 & 90.5 & 0.58 & 0.419 \\
\hline 8. Alepochori & 209.4 & 141.4 & 0.67 & 0.348 \\
\hline
\end{tabular}

\section{Conclusions}

The application of our simulation algorithm to the CGFS, based on an unsegmented model of earthquake generation, has shown quite satisfactory results both in the magnitude and in the timespace behaviour of the seismicity. The main conclusions drawn on these aspects can be summarised in the following.

1. The magnitude-distribution of the simulated seismicity is consistent with observations, which support a characteristic earthquake hypothesis.

2. The calculated average repeat times of strong earthquakes for each segment appear consistent with those inferred from the historical seismic catalog.

3. The long period of simulations has allowed us to obtain the statistical distribution of repeat time - an indispensable component for any seismic hazard analysis, which cannot be obtained from real observations, due to their short duration. The statistical distribution of earthquakes with $\mathrm{M}>6.0$ on single segments exhibits a fairly clear pseudo-periodic behaviour, with a coefficient of variation $C v$ of the order of 0.6. 
4. We have found clustering of the stronger events (multiplets) - a feature that can be inferred even from the limited time period covered by the observations.

5. None of the above reported conclusions need a segmented rupture model, but they are all consistent with a fully unsegmented seismogenic fault model.

6. The statistical features of the seismicity obtained from the simulation algorithm, easily computable from the long inter-event times series, can provide useful information for the seismic hazard assessment in the Corinth gulf area, in terms of occurrence probability of earthquakes exceeding a given magnitude for a given period of time in the future.

\section{References}

Ambraseys, N., 2009. Earthquakes in the Mediterranean and Middle East: a multidisciplinary study of seismicity up to 1900, Cambridge University Press, 947 pp., ISBN 9780521872928.

Armijo, R., Meyer, B., King, G.C.P., Rigo, A. and Papanastassiou, D., 1996. Quaternary evolution of the Corinth Rift and its implications for the Late Cenozoic evolution of the Aegean, Geophys. J. Int., 126, 11-53.

Baker, C., Hatzfeld, D., Lyon-Caen, H., Papadimitriou, E. and Rigo, A., 1997. Earthquake mechanisms of the Adriatic Sea and western Greece: implications for the oceanic subductioncontinental collision transition, Geophys. J. Intern., 131, 559-594.

Bernard, P., Briole, P., Meyer, B., Lyon-Caen, H., Gomez, J.M., Tiberi, C., Berge, C., Cattin, R., Hatzfeld, D., Lachet, C., Lebrun, B., Deschamps, A., Courboulex, F., Larroque, C., Rigo, A., Massonnet, D., Papadimitriou, P., Kassaras, J., Diagourtas, D., Makropoulos, K., Veis, G., Papazisi, E., Mitsakaki, C., Karakostas, V., Papadimitriou, E., Papanastassiou, D., Chouliaras, M. and Stavrakakis, G., 1997. The Ms=6.2, June 15, 1995 Aigion earthquake (Greece): evidence for low angle normal faulting in the Corinth rift, J. Seismology, 1, 131-150.

Billiris, H., Paradissis, D., Veis, G., England, P., Featherstone, W., Parsons, B., Cross, P., Rands, P., Rayson, M., Sellers, P., Ashkenazi, V., Davison, M., Jackson, J. and Ambraseys, N., 1991. Geodetic determination of tectonic deformation in central Greece from 1900 to 1988, Nature, $350,124-129$.

Briole, P., Rigo, A., Lyon-Caen, H., Ruegg, J.C., Papazissi, K., Mitsakaki, C., Balodimou, A., Veis, G., Hatzfeld, D. and Deschamps, A., 2000. Active deformation of the Corinth rift, Greece: Results from repeated Global Positioning surveys between 1990 and 1995, J. Geophys. Res., $105,25605-25625$.

Choussianitis, K., Ganas, A. and Gianniou, M., 2013. Kinematic interpretation of present-day crustal deformation in central Greece from continuous GPS measurements, J. Geodynamics, 71, 113.

Clarke, P.J., Paradisis, D., Briole, O., England, P.C., Parsons, B.E., Billiris, H., Veis, G. and Ruegg, J.C., 1997. Geodetic estimate of seismic hazard in the Gulf of Korinthos, Geophys. Res. Lett., 24, 1303-1306.

Console, R., Falcone, G., Karakostas, V., Murru, M., Papadimitriou, E. and Rhoades, D., 2013. Renewal models and coseismic stress transfer in the Corinth Gulf, Greece, fault system, $J$. Geophys. Res., 118, 3655-3673, doi: 10.1002/jgrb.50277.

Console, R., Carluccio, R., Papadimitriou, E. and Karakostas, V., 2015. Synthetic earthquake catalogs simulating seismic activity in the Corinth Gulf, Greece, fault system, J. Geoph. Res., 120, 1, 326-343, doi: 10.1002/2014JB011765.

Davies, R., England, P., Parsons, B., Billiris, H., Paradisis, D. and Veis, G., 1997. Geodetic strain of Greece in the interval 1892-1992, J. Geophys. Res., 102, 24,571-24,588.

Field, E.H., 2007. A summary of previous Working Groups on California Earthquake Probabilities, Bull. Seismol. Soc. Am., 97, 1033-1053.

Field, E.H. and Page, M.T., 2011. Estimating earthquake-rupture rates on a fault or fault system, Bull. Seismol. Soc. Am., 101(1), 79-92. 
Hatzfeld, D., Pedotti, G., Hatzidimitriou, P. and Makropoulos, K., 1990. The strain pattern in the western Hellenic arc deduced from a microearthquake survey, Geophys. J. Int., 101, 181-202.

Hatzfeld, D., Kementzetzidou, D., Karakostas, V., Ziazia, M., Nothard, S., Diagourtas, D., Deschamps, A., Karakaisis, G., Papadimitriou, P., Scordilis, M., Smith, R., Voulgarsi, N., Kiratzi, G., Makropoulos, K., Bouin, M.P. and Bernard, P., 1996. The Galaxidi earthquake sequence of November 18, 1992: a possible geometrical barrier within the normal fault system of the Gulf of Corinth (Greece), Bull. Seism. Soc. Am., 86, 1987-1991.

Hatzfeld, D., Karakostas, V., Ziazia, M., Kassaras, I., Papadimitriou, E., Makropoulos, K., Voulgaris, N. and Papaioannou, Ch., 2000. Microseismicity and faulting geometry in the Gulf of Corinth, Geophys. J. Intern., 141, 438-456.

Jackson, J.A., 1987. Active continental deformation and regional metamorphism, Phil. Trans. $R$. Soc. Lond., A321, 47-66.

Jackson, J.A. and McKenzie, D.P., 1988. The relationship between plate motions and seismic tensors, and the rate of active deformation in the Mediterranean and Middle East, Geophys. Journal, 93, 45-73.

Jackson, J.A, and White, N.J., 1989. Normal faulting in the upper continental crust: observations from regions of active extension, J. Struct. Geol., 11, 15-36.

McKenzie, D., 1978. Active tectonics of the Alpine-Himalayan belt: the Aegean Sea and surrounding regions, Geophys. J. R. Astr. Soc., 55, 217-254.

Papazachos, B.C. and Papazachou, C., 2003. The earthquakes of Greece, Ziti Publ., Thessaloniki, Greece, 317 pp.

Parsons, T., 2012. Paleoseismic interevent times interpreted for an unsegmented earthquake rupture forecast, Geophys. Res. Lett., 99, L13302, doi: 10.1029/2012GL052275.

Reid, H.F., 1910. The mechanics of the earthquake, the California earthquake of April 18, 1906: report of the State Earthquake Investigation Commission, publication no. 87, Carnegie Institution of Washington, II, $192 \mathrm{pp}$.

Rigo, A., Lyon-Caen, H., Armijo, R., Deschamps, A., Hatzfeld, D., Makropoulos, K., Papadimitriou, P. and Kassaras, I., 1996. Microseismicity study in the western part of the Gulf of Corinth (Greece): Implications for large-scale normal faulting mechanisms, Geophys. J. Int., 126, 663-688.

Richards-Dinger, K. and Dieterich, J.H., 2012. RSQSim earthquake simulator, Seism. Res. Lett., 6, 983-990, doi: 10.1785/0220120105.

Schwartz, D.P. and Coppersmith, K.J., 1984. Fault behaviour and characteristic earthquakes: examples from the Wasatch and San Andreas Fault Zones, J. Geophys. Res., 89, 5681-5698.

Shimazaki, K and Nakata, T., 1980. Time-predictable recurrence model for large earthquakes, Geophys. Res. Lett., 7, 279-282.

Taymaz, T., Jackson, J. and McKenzie, D., 1991. Active tectonics of the north and central Aegean, Geophys. J. Int., 106, 433-490.

Tullis, T.E., 2012. Preface to the Focused Issue on Earthquake Simulators, Seism. Res. Lett., 83, 6, 957-958.

Ward, S.N., 2012. ALLCAL Earthquake Simulator, Seism. Res. Lett., 83, 964-972.

Weldon, R.J., Fumal, T.E., Biasi, G.P. and Scharer, K.M., 2005. Past and future earthquakes on the San Andreas fault, Science, 308, 5724, 966-967, doi: 10.1126/science.1111707.

WGCEP, Working Group on California Earthquake Probabilities, 2008. The Uniform California Earthquake Rupture Forecast, Version 2 (UCERF 2), USGS Open File Report 2007-1437, CGS Special Report 203, SCEC Contribution \#1138, Version 1.0, 104 pp. 